\title{
Germ Cell Tumor
}

National Cancer Institute

\section{Source}

National Cancer Institute. Germ Cell Tumor. NCI Thesaurus. Code C3708.

A benign or malignant, gonadal or extragonadal neoplasm that originates from germ

cells. Representative examples include teratoma, seminoma, embryonal carcinoma, and yolk sac tumor. 